\title{
GMR
}

\section{Role of PPAR $\alpha$ in down-regulating AGE-induced TGF- $\beta$ and MMP-9 expressions in chondrocytes}

\author{
J. Wang', G. Wang ${ }^{2}$ and G.W. Sun ${ }^{1}$ \\ ${ }^{1}$ Department of Bone Trauma, Inner Mongolia People's Hospital, \\ Hohhot, China \\ ${ }^{2}$ Department of Traumatic Orthopedics, Nanfang Hospital, \\ Southern Medical University, Guangzhou, China \\ Corresponding author: J. Wang \\ E-mail: wangjianimph@163.com
}

Genet. Mol. Res. 15 (2): gmr.15027963

Received August 30, 2015

Accepted January 6, 2016

Published May 6, 2016

DOI http://dx.doi.org/10.4238/gmr.15027963

\begin{abstract}
Peroxisome proliferator-activated receptor is closely associated with the pathogenesis of osteoarthritis. The level of exogenous advanced glycation end-products (AGEs) in articular cartilage is highly associated with the severity of osteoarthritic lesions. However, their interactions and role in promoting osteoarthritisprogression remain unclear. Here, we investigated the effect of AGEs on transforming growth factor (TGF)- $\beta$ and matrix metalloproteinase (MMP)- 9 expression, and discussed the correlation between AGEs and osteoarthritis, possible signaling pathways and mechanism in rabbit chondrocytes. TGF- $\beta$ and MMP-9 mRNA and protein expression, catalase (CAT) and superoxide dismutase (SOD) activity, and malondialdehyde (MDA) and reactive oxygen species (ROS) levels were analyzed in chondrocytes treated with different concentrations of AGEs using RT-PCR and/or western blot; we detected NF- $\kappa B$ nuclear translocation by immunofluorescence. AGE treatment significantly increased TGF- $\beta$ and MMP-9 mRNA and protein expression compared to controls $(\mathrm{P}<0.01)$ in a dose-dependent manner (highest at $100 \mu \mathrm{g} / \mathrm{mL}$ ). AGE-induced TGF- $\beta$ and MMP-9 expressions in chondrocytes were significantly inhibited by anti-RAGE
\end{abstract}


and PDTC $(0.1 \mathrm{mM})$ treatment $(\mathrm{P}<0.01)$. Furthermore, AGE-treatment significantly decreased CAT and SOD activity and increased MDA levels in a concentration-dependent manner compared to controls ( $\mathrm{P}$ $<0.05$ ), significantly promoting NF- $\mathrm{BB}$ nuclear translocation. AGE significantly inhibited the increased expression of TGF- $\beta$ and MMP9 , and induced chondrocyte damage. Its mechanism is associated with RAGE activation, increased ROS expression, and activation of the NF$\kappa \mathrm{B}$ signaling pathways.

Key words: Advanced glycation end-products; Chondrocytes; NF-кB; Reactive oxygen species; TGF- $\beta$; Matrix metalloproteinase- 9

\section{INTRODUCTION}

Osteoarthritis (OA) is the most common disease affecting the motor system (Zhang et al., 2010). It is a chronic joint disease with a morbidity that increases significantly with age. The total morbidity of OA is $35.87 \%$ in people aged $>40$ years, $50 \%$ in people aged above 60 years, and $80 \%$ in patients aged $>75$ years. The disability rate of this disease is as high as 53\% (Matsui et al., 2010). The cause of OA and the specific pathogenesis, however, remains unclear (Hemmings et al., 2015). The development of OA in the joints leads to an increase in the expression and content of various matrix metalloproteinases (MMPs) and a corresponding increase in the decomposition of cartilage mesenchyme. The degradation products of the cartilage mesenchyme molecules promote further degradation, forming a continuous vicious circle (Koh et al., 2013). MMP-9 is an enzyme with the ability to decompose type II collagen. It plays an important role in the incidence and progression of OA (Gondret et al., 2012; Mahali and Manna, 2012). Some cytokines secreted from the diseased region can significantly damage the articular cartilage and synovial membrane. TGF- $\beta$ is a particularly important cytokine that is expressed during early OA (Bakala et al., 2013). Therefore, TGF- $\beta$ and MMP-9 can serve as experimental observational indices for judging the onset and severity of $\mathrm{OA}$; this also accounts for these factors being the main objects of observation in OA research.

OA incidence has been associated with many factors, including heredity, development, metabolism, trauma. An increase in age leads to the generation and accumulation of a large number of advanced glycation end-products (AGEs) (Bian et al., 2013). AGEs are stable covalent compounds (Lee et al., 2013) derived from non-enzymatic glycosylation reactions between proteins, lipids, and glucose or other reducing monosaccharides. AGE generation is an unavoidable and irreversible process (Fu et al., 2014). Research has demonstrated that the generation and accumulation of a large number of AGEs in vivo play a vital role in the development and acceleration of OA (Mahmoud and Elshazly, 2014); moreover, these act as the molecular foundation for the effect of age on OA. However, its mechanism remains unclear.

Previous studies have discovered a close association between peroxisome proliferatoractivated receptor (PPAR) and the pathogenic mechanism of osteoarthritis (Lee et al., 2012; Rahigude et al., 2012; Chen et al., 2015). Thiazolidinediones such as pioglitazone, rosiglitazone, and troglitazone are the major synthetic ligands of PPAR $\alpha$ that have found clinical application (Mahali et al., 2014). Previously, PPARawas believed to participate mainly in the regulation of lipid metabolism. Recent research has also indicated their role in 
the regulation of inflammatory reactions, substrate decomposition, and synthesis (as a signal assembly complex) (Xu et al., 2011).

OA acceleration is mainly attributed to the generation and accumulation of a number of AGEs. Therefore, these processes are believed to be the molecular foundation of the effect of age on OA (Wang et al., 2011). AGEs and RAGE play a role in (forming a complex) increasing the levels of IL-1, TGF- $\beta$, and MMP-9 (Devi and Sudhakaran, 2012) during cellular secretion and synthesis. OA patients and animal models are known to show a significant decrease in the expression of PPAR $\alpha$. Moreover, PPAR $\alpha$ expression has been associated with oxidative stress in osteoarthritis animal models, as well as the pathological process of osteoarthritis arising from AGEs (Baibergenova and Walsh, 2012). Therefore, it may be a critical aspect influencing the cellular signal transduction pathways (Kuo et al., 2012). Here, we describe three experiments performed to verify this hypothesis. AGEs were applied as damage factors in in vitro articular cartilage models, and PPAR $\alpha$ expression was observed. A specific agonist was used to further define the relationship between PPAR $\alpha$ and AGE-induced osteoarthritis, to explain the protective effect of the PPAR $\alpha$ ligand and the signal transcription pathway in AGEs, and identify the cells mediated by their receptor RAGE.

\section{MATERIAL AND METHODS}

\section{Experimental animals}

Healthy and clean male New Zealand white rabbits aged 5 weeks and weighing approximately 1.2-1.5 kg were obtained from the Laboratory Animal Department of the Inner Mongolia University (Hohhot, China); all animal experiments were approved by the Ethics Committee of the Inner Mongolian Hospital.

\section{Experimental design and grouping}

The animals were divided into the 1) control group; 2) BSA (100 $\mu \mathrm{g} / \mathrm{mL})$ control group; 3) AGE (1 $\mu \mathrm{g} / \mathrm{mL})$ treatment group; 4) AGE $(10 \mu \mathrm{g} / \mathrm{mL})$ treatment group; 5) AGE $(25 \mu \mathrm{g} / \mathrm{mL})$ treatment group; 6) AGE $(50 \mu \mathrm{g} / \mathrm{mL})$ treatment group; and 7) AGE (100 $\mu \mathrm{g} /$ $\mathrm{mL}$ ) treatment group $(\mathrm{N}=8$ each). The catalase (CAT) (Beyotime, Jiangsu, China) and superoxide dismutase(SOD) (Beyotime) activities and malondialdehyde (MDA) content in the chondrocytes after treatment with different concentrations of AGEs for $48 \mathrm{~h}$ were determined. Reactive oxygen species (ROS) concentration was detected using the fluorescent probe DCFH-DA (R\&D Systems, Minneapolis, MN, USA). TGF- $\beta$ and MMP-9 expression in the chondrocytes was detected by RT-PCR.

\section{Detection of CAT activity}

Cells in the treatment group were decomposed with the lysis solution and subsequently centrifuged for $10 \mathrm{~min}$ at $1600 \mathrm{~g}$ at $4^{\circ} \mathrm{C}$. Simultaneously, the detection agent was prepared in accordance with the manufacturer instructions. The supernatant $(20 \mu \mathrm{L})$ and reagent were mixed thoroughly with a pipette; this was incubated with the color development working solution for $15 \mathrm{~min}$ at $25^{\circ} \mathrm{C}$ to terminate the reaction. The absorbance was determined at 520 $\mathrm{nm}$ using a microplate reader. The CAT activity was calculated using the appropriate formula. 


\section{Detection of SOD activity}

Cells in the treatment groups were lysed, centrifuged for $10 \mathrm{~min}$ at $1600 \mathrm{~g}$ at $4{ }^{\circ} \mathrm{C}$, and the supernatant $(10 \mu \mathrm{L})$ was mixed with the pre-mixed reagent (according to the manufacturer instructions) using a vortex mixer. This mixture was then placed in a thermostatic water bath for $20 \mathrm{~min}$ at $37^{\circ} \mathrm{C}$. The mixture was then incubated with the color-developing agent for 10 min at room temperature. The absorbance value was determined at $560 \mathrm{~nm}$ with a microplate reader. The SOD activity was calculated using the standard formula.

\section{Detection of MDA content}

The MDA reagent was prepared in accordance with the kit instructions (Lin et al., 2012). The sample $(0.1 \mu \mathrm{L})$ was mixed with an equal volume of the reagent in a $0.5-\mathrm{mL}$ PCR tube using a vortex mixer, and incubated in a $100^{\circ} \mathrm{C}$ water bath for $10 \mathrm{~min}$. The tube was then cooled to room temperature with running water. The supernatant $(200 \mu \mathrm{L})$ was then added to each well of a 96-well microplate. The absorbance was determined at $532 \mathrm{~nm}$ with an ABI PE microplate reader (Applied Biosystems, Foster City, CA, USA). The MDA concentration was calculated using the standard formula.

\section{Detection of oxygen-free radical (ROS) level in cells}

The fluorescent probe DCFH-DA was used to detect ROS expression. DCFH-DA (R\&D Systems) was diluted (1:2000) with serum-free Dulbecco's modified Eagle's medium (DMEM) (MOEL, Huhhot, China). The cell culture medium was replaced with $1 \mathrm{~mL}$ diluted DCFH-DA and incubated for $20 \mathrm{~min}$ in a $37^{\circ} \mathrm{C}$ incubator. The cells were washed thrice with serum-free DMEM to completely remove the excess DCFH-DA. The cells were then observed under a fluorescence microscope.

\section{RT-PCR}

cDNA was synthesized by reverse transcription. The primers were designed with Primer Express 2.0 (Tree Star Inc., Ashland, OR, USA). The melting temperature was set at $58^{\circ}-60^{\circ} \mathrm{C}$. The following primers were used for PCR: TGF- $\beta$ : $5^{\prime}$-GTGATCTAGTGCTAGTGA TCGATCTG-3'; MMP-9: 5'-CTAGCTGTAGTGCAGTCGATGCT-3'; GAPDH: 5'-TTCATTG CTGTCAGTCGTAC-3'. The samples were amplified with the Bio-Rad 7500 (Bio-Rad, Hercules, CA, USA) under the following cycling conditions: initial denaturation at $95^{\circ} \mathrm{C}$ for 4 min, 36 cycles at $95^{\circ} \mathrm{C}$ for $30 \mathrm{~s}, 60^{\circ} \mathrm{C}$ for $32 \mathrm{~s}$, and $72^{\circ} \mathrm{C}$ for $40 \mathrm{~s}$. The melting curve process was also performed. The SDS software (Costa Mesa, CA, USA) for the 7500 quantitative PCR amplifier was used for data analysis, according to the program instructions.

\section{Western blot}

Total protein was extracted and its concentration determined using the standard BCA method. Thirty micrograms of the protein was loaded, electrophoresed, and transferred to a membrane (constant voltage $100 \mathrm{~V}, 1 \mathrm{~h}$ ), where the protein was blocked, washed, and incubated 
with the primary antibody PPAR (Abcam, Cambridge, UK). Subsequently, the membrane was washed thrice for $10 \mathrm{~min}$, incubated for $1 \mathrm{~h}$ at room temperature with the HRP-labeled specific secondary antibodies (1:1000) (Boster, Wuhan, China), and washed again. The membrane was developed and analyzed using actin as the internal reference.

\section{Statistical analysis}

All data are reported as means \pm standard deviation (means \pm SD). The differences among various groups were compared by analysis of variance (ANOVA) Newman-Student. Multiple comparisons were performed using the $t$-test. All analyses were performed with SPSS v.16.0 (IBM, Armonk, NY, USA). The differences were considered to be statistically significant when $\mathrm{P}<0.05$.

\section{RESULTS}

\section{Effect of AGEs on TGF- $\beta$ and MMP-9 expression in chondrocytes}

The chondrocytes were incubated with AGEs at different concentrations $(1,10$, 25,50 , and $100 \mu \mathrm{g} / \mathrm{mL}$ ) for $48 \mathrm{~h}$, and the expression of $T G F-\beta$ and $M M P-9$ mRNA in the treated chondrocytes were determined by RT-PCR. We observed a significant increase in the expression of $T G F-\beta$ and $M M P-9$ mRNA in the AGE-treated chondrocytes, compared to the controls $(\mathrm{P}<0.05)$.

This effect was most significant at an AGE concentration of $100 \mu \mathrm{g} / \mathrm{mL}$, which showed an increase in the TGF- $\beta$ :GAPDH and MMP-9:GAPDH ratios from $0.61 \pm 0.02$ to $1.79 \pm 0.03$ $(\mathrm{P}<0.01)$ and $0.78 \pm 0.02$ to $1.87 \pm 0.04(\mathrm{P}<0.01)$. We observed no statistically significant differences between the BSA and normal control groups ( $\mathrm{P}>0.05$; Figure 1$)$.
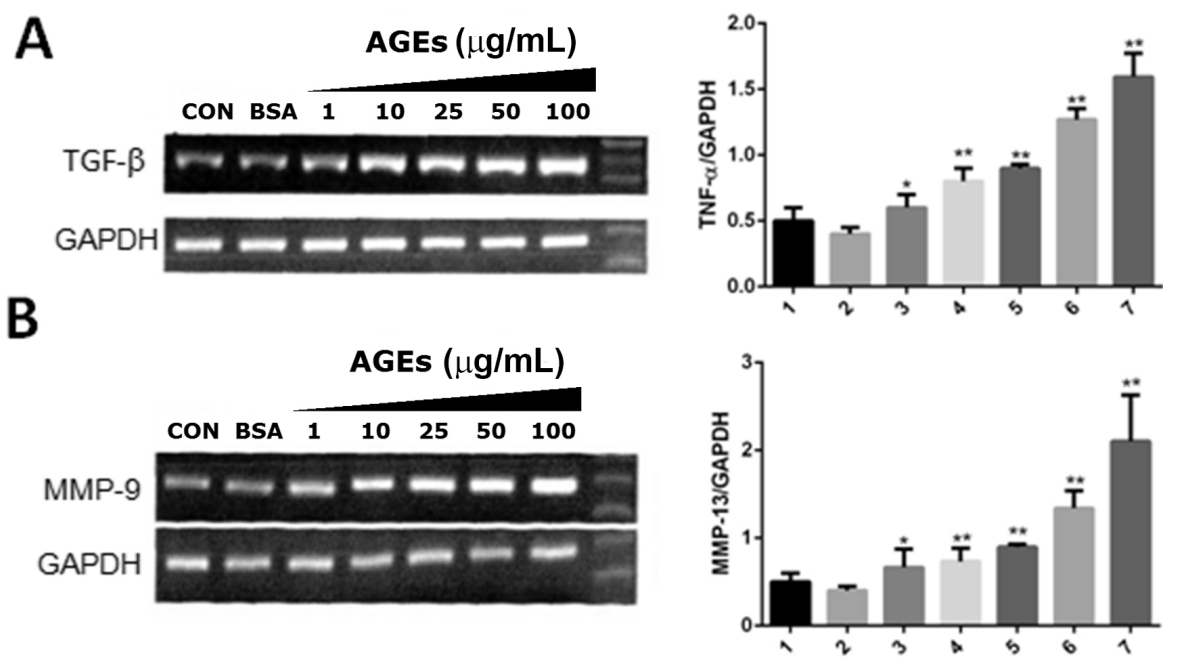

Figure 1. Effect of different concentrations of AGE on the expression of (A) TGF- $\beta$ and (B) MMP-9 mRNA in chondrocytes, as detected by RT-PCR. All data arereported as means $\pm \mathrm{SD} ; \mathrm{N}=8$ per group. ${ }^{*} \mathrm{P}<0.05,{ }^{*} * \mathrm{P}<0.01$ $v s$ the normal control group $(\mathrm{CON})$. 
Dose-response relationship between AGEs and PPAR $\alpha$ expression in in vitro cultured chondrocytes

We then detected the mRNA and protein levels of PPAR $\alpha$ in AGE-treated chondrocytes by RT-PCR and western blot, respectively. The BSA and normal control groups did not differ significantly $(\mathrm{P}>0.05)$. AGE treatment caused a significant decrease in PPAR $\alpha$ mRNA and protein content in the chondrocytes compared to the normal control chondrocytes $(\mathrm{P}<0.05)$. Treatment with $100 \mu \mathrm{g} / \mathrm{mL}$ AGE caused the least significant effect (Figure 2).
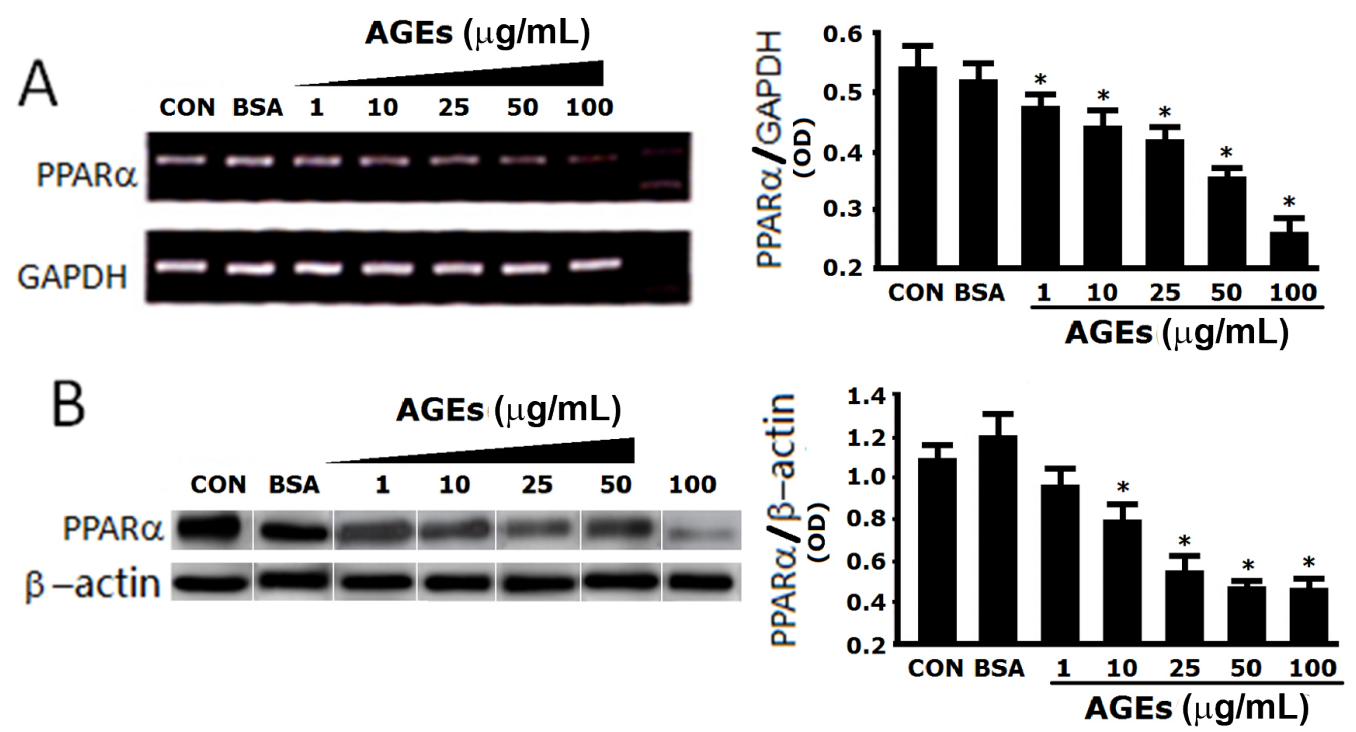

Figure 2. Effect of different concentrations of AGEs PPAR (A) mRNA and (B) protein expression in chondrocytes, as detected by RT-PCR and westernblot, respectively. All data are reported as means $\pm \mathrm{SD} ; \mathrm{N}=8$ per group. $* \mathrm{P}<$ 0.05 vs normal control group (CON).

The PPAR mRNA and protein levels in cultured chondrocytes treated with $100 \mu \mathrm{g} /$ $\mathrm{mL}$ exogenous AGE for $0,3,6,12,24$, and $48 \mathrm{~h}$ were determined by RT-PCR and western blot, respectively (Figure 3). We observed a statistically significant difference in PPAR mRNA and protein expression between the 0 -h treatment group and other groups $(\mathrm{P}<0.05)$, with the mRNA and protein expression being lowest in the $48 \mathrm{~h}$ group. The PPAR mRNA expression and protein content was shown to decrease with time.

\section{PPAR $\alpha$ expression in chondrocytes cultured in vitro}

The JNK, P38, and ERK signaling pathways of the MAPK family were blocked 30 min prior to the AGE treatment (for $48 \mathrm{~h}$ ). The PPAR $\alpha$ mRNA and protein expressions were detected by RT-PCR and western blot, respectively. Addition of the three blocking agents individually did not significantly influence the RT-PCR and western blot results of the treatment and normal control groups $(\mathrm{P}>0.05)$. However, co-incubation of the chondrocytes 
with the blocking agents SP600125 and SB203580 (specific for the JNK and P38-MAPK signal pathways) prior to AGE treatment led to a significant increase in the PPAR $\alpha$ mRNA and protein levels compared to those in cells treated with AGEs alone $(\mathrm{P}<0.05)$; moreover, this increase was proportional to the concentration of the blocking agent. We also observed no significant difference in PPAR $\alpha$ mRNA and protein expression between the group treated with the blocking agent PD98059 (specific for the ERK pathway; 3 concentrations) prior to AGE treatment, and the AGE-treated group ( $\mathrm{P}>0.05$; Figure 4$)$.

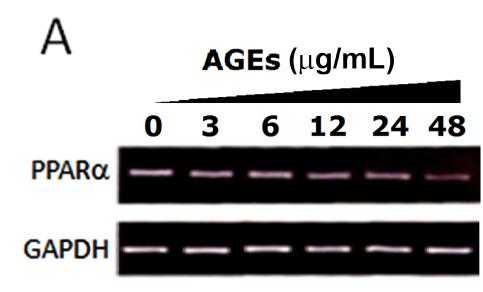

B

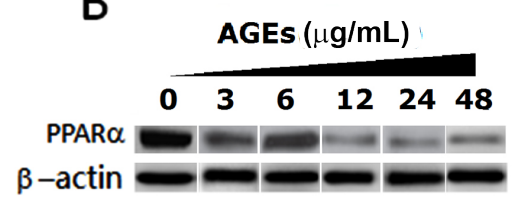

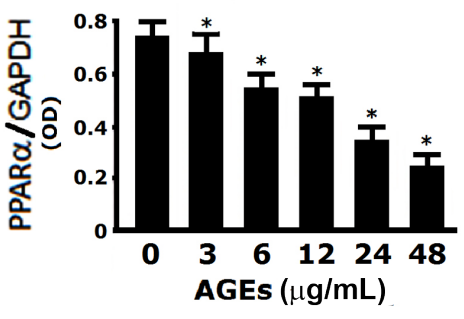

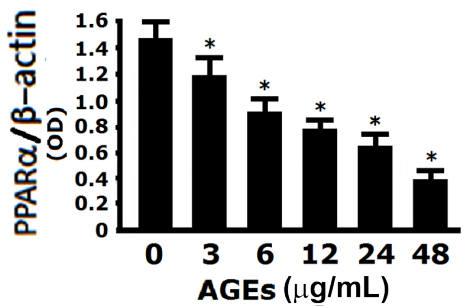

Figure 3. Effect of AGEs on PPAR (A) mRNA and (B) protein content in chondrocytes at different time points, as detected by RT-PCR and westernblot, respectively. All data are reported as means $\pm \mathrm{SD}(\mathrm{N}=8$ per group).
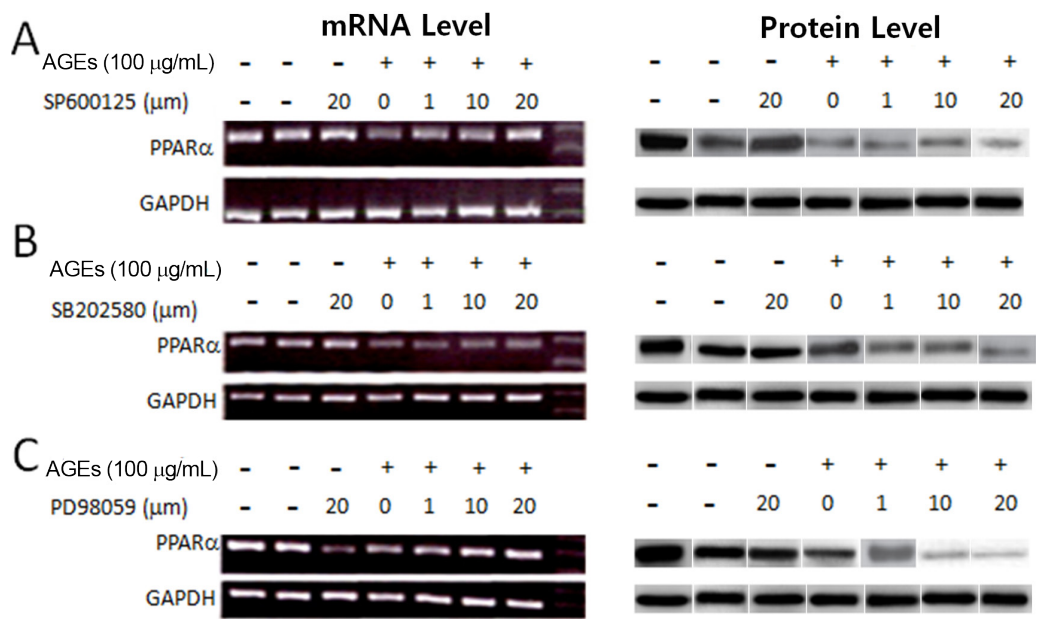

Figure 4. Effect of different concentrations of pathway blocking agents (A) SP600125 (against the JNK-MAPK pathway), (B) SB203580 (against the P38-MAPK pathway), and (C) PD98059 (against the ERK-MAPK pathway) on the regulatory role of AGEs in PPAR mRNA and protein expression in chondrocytes. All data are reported as means $\pm \mathrm{SD}(\mathrm{N}=8$ per group). 


\section{Effect of pioglitazone on AGE-induced CAT and SOD activity and MDA content in chondrocytes}

The chondrocytes were pre-incubated with 1,10 , and $50 \mu \mathrm{M}$ pioglitazone for $2 \mathrm{~h}$, and subsequently co-incubated with $100 \mu \mathrm{g} / \mathrm{mL}$ AGE for $48 \mathrm{~h}$. CAT, SOD, and MDA expressions were detected in accordance with the kit instructions.

We observed that pioglitazone had a dose-dependent antagonistic action on CAT activity (Figure 5A) and SOD (Figure 5B), while positively affecting MDA expression (Figure $5 \mathrm{C})$ in cells treated with AGEs $(\mathrm{P}<0.05)$, with the $50 \mu \mathrm{M}$ pioglitazone exerting the most significant effect.
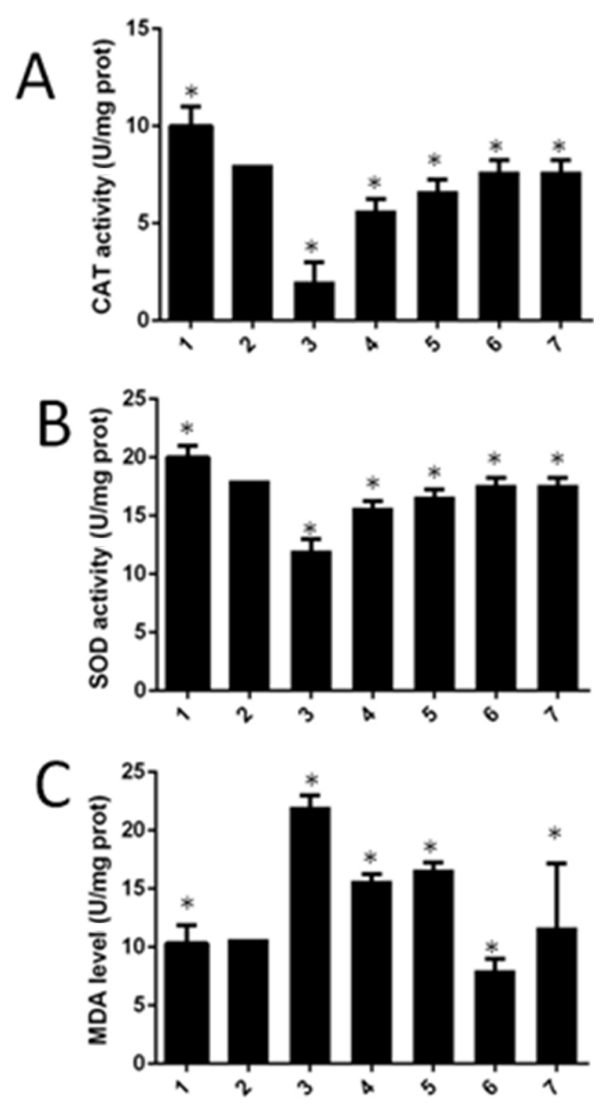

Figure 5. Effect of different concentrations of pioglitazone on AGE-induced (A) CAT and (B) SOD activity, and (C) MDA level in chondrocytes. Columns: 1. control; 2. BSA $(100 \mu \mathrm{g} / \mathrm{mL}) ; 3.100 \mu \mathrm{g} / \mathrm{mL}$ AGE; $4.100 \mu \mathrm{g} / \mathrm{mL}$ AGE + pioglitazone $(1 \mu \mathrm{M}) ; 5.100 \mu \mathrm{g} / \mathrm{mL}$ AGE + pioglitazone $(10 \mu \mathrm{M}) ; 6.100 \mu \mathrm{g} / \mathrm{mL}$ AGE + pioglitazone $(50 \mu \mathrm{M}) ; 7$. pioglitazone $(50 \mu \mathrm{M})$. All data are reported as means $\pm \mathrm{SD}\left(\mathrm{N}=8\right.$ per group). ${ }^{*} \mathrm{P}<0.05$ s the AGE treatment group.

\section{Effect of pioglitazone on AGE-induced activation of NF- $\kappa \mathrm{B}$ in chondrocytes}

The chondrocytes were pre-incubated with 1,10 , and $50 \mu \mathrm{M}$ pioglitazone for $2 \mathrm{~h}$, and subsequently co-incubated with $100 \mu \mathrm{g} / \mathrm{mLAGE}$ for $48 \mathrm{~h}$. NF- $\mathrm{kB}$ P 65 nuclear translocation was 
directly detected using the fluorescence method (Figure 6). The AGE treatment significantly promoted nuclear translocation of chondrocyte P65, which was significantly inhibited by pioglitazone pre-treatment in a dose-dependent manner; the effect of pioglitazone on the 100 $\mu \mathrm{g} / \mathrm{mL}$ AGE treatment group was significantly higher than that in the normal control group (P $<0.05)$. On the other hand, we observed no statistically significant difference between the 50 $\mu \mathrm{M}$ pioglitazone treatment group and the normal control group. The NF- $\kappa \mathrm{B}$ protein content, detected by western blot, was consistent to the results of the fluorescence method.

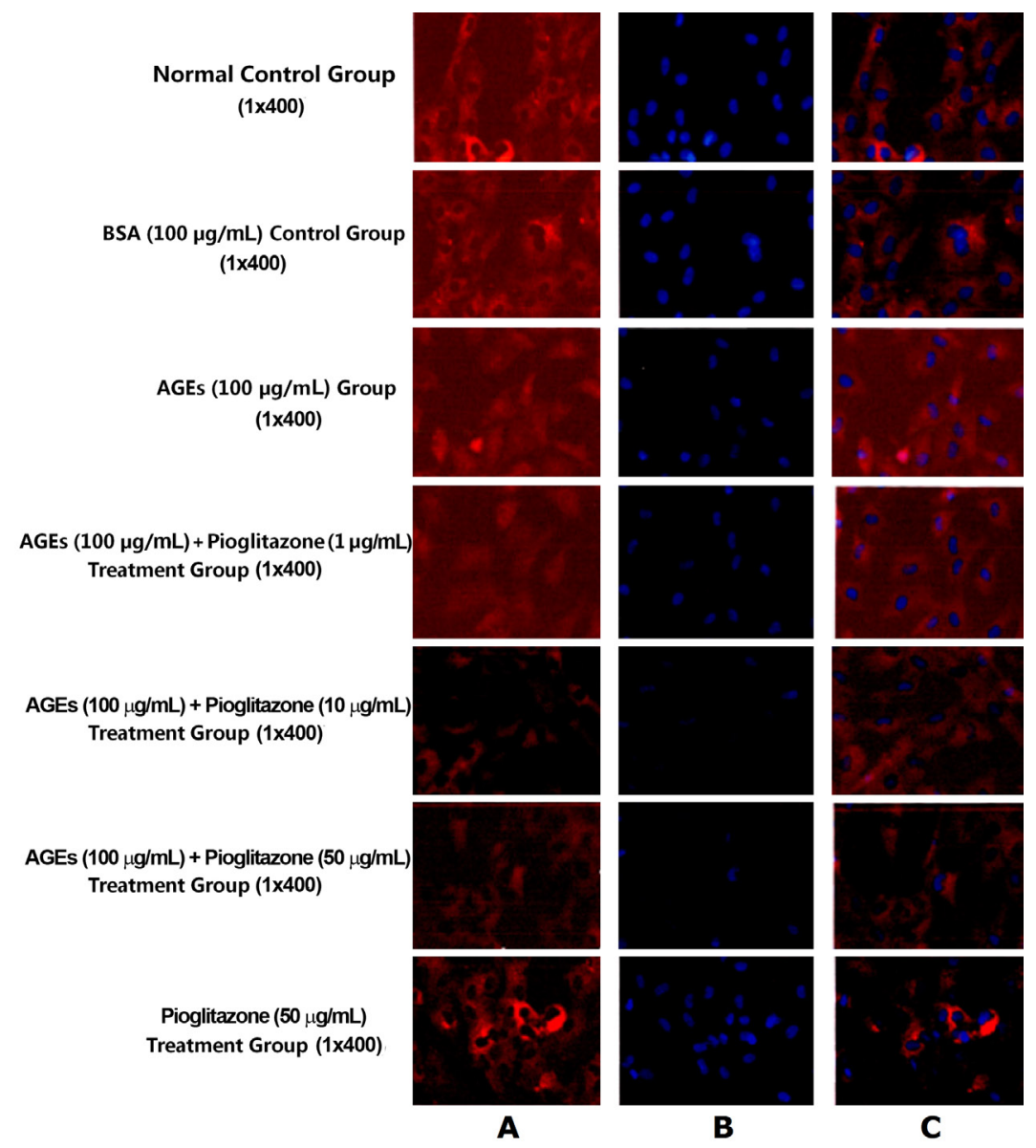

Figure 6. Effect of different concentrations of pioglitazone on AGE and induced NF- $\mathrm{KB}$ protein content in chondrocytes. A. P65 expression. B. DAPI nuclear staining. C. Nuclear translocation was obvious in the merged diagram. The AGE treatment group significantly promoted nuclear translocation of P65 in chondrocytes. Pioglitazone significantly inhibited this effect of AGEs. The effect was strengthened by the increase in dosage. All data are reported as means $\pm \mathrm{SD}(\mathrm{N}=8$ per group).

\section{DISCUSSION}

A considerable amount of research conducted over the past few years has indicated a close association between AGEs and the incidence and progression of OA. Some scholars 
even believe that AGEs play a key role in the molecular mechanism of the OA age risk factor; however, the mechanism remains unclear. Currently, the mechanism of AGE-induced $\mathrm{OA}$ is believed to follow a direct or indirect route. AGE directly leads to collagen glycation, crosslinking, decreased proteoglycan synthesis in the matrix, increased matrix brittleness, and a significant decrease in compressive resistance and shearing resistance capacity. AGEs are highly expressed on longevity proteins. The half-life period of collagen, the major component of the cartilage matrix, is $>100$ years, contributing to the easy formation and accumulation of AGEs. The collagen is further cross-linked following glycation, thus damaging the cartilage matrix structure and function and hardening and embrittling the articular cartilage. Therefore, cartilage is damaged even under a normal physiological load (Furukawa et al., 2013). Secondly, the formation and deposition of AGEs in tissue can accelerate aging and tissue hypofunction. The results of this experiment have shown that AGEs significantly induce the expression of TGF- $\beta$ and MMP-9 in chondrocytes in a highly concentration-dependent manner. This demonstrates the damaging effect of AGEs on chondrocytes.

PPAR influences multiple-cellular processes including lipid metabolism, homeostasis, cell cycle, cell differentiation, inflammation, and extracellular matrix reconstruction by regulating the transcriptional level of the relevant genes. Down-regulation of PPAR $\alpha$ in chondrocytes can lead to structural and functional changes in chondrocytes, such as a decrease in secretions by the chondrocyte matrix, increase in secretions by the matrix metalloproteinase, and increase in number of inflammatory factors and cytokines (Chen and Zhong, 2013). Here, we have demonstrated the antagonistic effect of AGEs on chondrocyte PPAR in a concentrationand time-dependent manner. MAPK regulates multiple-cellular physiological processes such as cellular proliferation, differentiation, transformation, and apoptosis through primers such as phosphorylated transcription factors, cytoskeleton-related proteins, and enzymes (Chen et al., 2013). The chondrocytes were pre-incubated with blocking agents for the three signal pathways of MAPKs (JNK, P38, and ERK) for $30 \mathrm{~min}$, and then incubated for $48 \mathrm{~h}$ with or without AGEs. The PPAR $\alpha$ mRNA and protein levels were then detected with RT-PCR and westernblot, respectively. The signaling pathways of P38-MAPK and JNK-MAPK were thus found to participate in AGE-induced down-regulation of PPAR $\alpha$ expression in chondrocytes.

Previous studies reported that the generation of a large amount of ROS is the initial link to the AGEs/RAGE signaling pathways. Here, we determined that the AGE treatment group can significantly promote nuclear translocation of NF- $\mathrm{KB}$ P65 in chondrocytes. Pioglitazone can significantly inhibit such an effect in a dose-dependent manner (Antonopoulou et al., 2013). The results of this study indicated that pioglitazone protects against AGE-induced cartilage injury, providing a theoretical and experimental basis for clinical treatment of OA, identification of novel therapeutic targets, and the development of novel drugs.

\section{Conflicts of interest}

The authors declare no conflict of interest.

\section{ACKNOWLEDGMENTS}

Research supported by the Natural Science Foundation of the Inner Mongolia Autonomous Region (\#2014MS08136). 


\section{REFERENCES}

Antonopoulou M, Bahtiyar G, Banerji MA and Sacerdote AS (2013). Diabetes and bone health. Maturitas 76: 253-259. http://dx.doi.org/10.1016/j.maturitas.2013.04.004

Baibergenova A and Walsh S (2012). Use of pioglitazone in patients with lichen planopilaris. J. Cutan. Med. Surg. 16: 97-100.

Bakala H, Ladouce R, Baraibar MA and Friguet B (2013). Differential expression and glycative damage affect specific mitochondrial proteins with aging in rat liver. Biochim. Biophys. Acta 1832: 2057-2067.http://dx.doi.org/10.1016/j. bbadis.2013.07.015

Bian D, Zhang J, Wu X, Dou Y, et al. (2013). Asiatic acid isolated from Centellaasiatica inhibits TGF-b1-induced collagen expression in human keloid fibroblasts via PPAR- $\gamma$ activation. Int. J. Biol. Sci. 9: 1032-1042. http://dx.doi. org/10.7150/ijbs. 7273

Chen YJ, Sheu ML, Tsai KS, Yang RS, et al. (2013). Advanced glycation end products induce peroxisome proliferatoractivated receptor $\gamma$ down-regulation-related inflammatory signals in human chondrocytes via Toll-like receptor-4 and receptor for advanced glycation end products. PLoS One 8: e66611. http://dx.doi.org/10.1371/journal.pone.0066611

Chen YJ, Chan DC, Lan KC, Wang CC, et al. (2015). PPAR $\gamma$ is involved in the hyperglycemia-induced inflammatory responses and collagen degradation in human chondrocytes and diabetic mouse cartilages. J. Orthop. Res. 33: 373381. http://dx.doi.org/10.1002/jor. 22770

Chen Z and Zhong C (2013). Decoding Alzheimer's disease from perturbed cerebral glucose metabolism: implications for diagnostic and therapeutic strategies. Prog. Neurobiol. 108:21-43. http://dx.doi.org/10.1016/j.pneurobio.2013.06.004

Devi MS and Sudhakaran PR (2012). Angiogenic response of advanced glycation end products (AGEs) involves PPARgamma. Indian J. Biochem. Biophys. 49: 18-24.

Fu RQ, Liu RR, Zhao GP, Zheng MQ, et al. (2014). Expression profiles of key transcription factors involved in lipid metabolism in Beijing-You chickens. Gene 537: 120-125. http://dx.doi.org/10.1016/j.gene.2013.07.109

Furukawa M, Gohda T, Tanimoto M and Tomino Y (2013). Pathogenesis and novel treatment from the mouse model of type 2 diabetic nephropathy. Sci. World J. 2013: 928197. http://dx.doi.org/10.1155/2013/928197

Gondret F, Riquet J, Tacher S, Demars J, et al. (2012). Towards candidate genes affecting body fatness at the SSC7 QTL by expression analyses. J. Anim. Breed. Genet. 129: 316-324. http://dx.doi.org/10.1111/j.1439-0388.2011.00965.x

Hemmings KM, Daniel ZC, Buttery PJ, Parr T, et al. (2015). Differential effects of short-term $\beta$ agonist and growth hormone treatments on expression of myosin heavy chain IIB and associated metabolic genes in sheep muscle. Animal 9: 285-294. http://dx.doi.org/10.1017/S175173111400233X

Koh EJ, Yoon SJ and Lee SM (2013). Losartan protects liver against ischaemia/reperfusion injury through PPAR- $\gamma$ activation and receptor for advanced glycation end-products down-regulation. Br. J. Pharmacol. 169: 1404-1416. http://dx.doi.org/10.1111/bph.12229

Kuo TY, Huang CL, Yang JM, Huang WJ, et al. (2012). The role of ribosylated-BSA in regulating PC12 cell viability. Cell Biol. Toxicol. 28: 255-267. http://dx.doi.org/10.1007/s10565-012-9220-3

Lee BH, Hsu WH, Chang YY, Kuo HF, et al. (2012). Ankaflavin: a natural novel PPAR $\gamma$ agonist upregulates Nrf2 to attenuate methylglyoxal-induced diabetes in vivo. Free Radic. Biol. Med. 53: 2008-2016. http://dx.doi.org/10.1016/j. freeradbiomed.2012.09.025

Lee TI, Kao YH, Chen YC, Huang JH, et al. (2013). The dipeptidyl peptidase-4 inhibitor-sitagliptin modulates calcium dysregulation, inflammation, and PPARs in hypertensive cardiomyocytes. Int. J. Cardiol. 168: 5390-5395. http:// dx.doi.org/10.1016/j.ijcard.2013.08.051

Lin J, Tang Y, Kang Q and Chen A (2012). Curcumin eliminates the inhibitory effect of advanced glycation end-products (AGEs) on gene expression of AGE receptor-1 in hepatic stellate cells in vitro. Lab. Invest. 92: 827-841. http:// dx.doi.org/10.1038/labinvest.2012.53

Mahali SK and Manna SK (2012). Beta-D-glucoside protects against advanced glycation end products (AGEs)-mediated diabetic responses by suppressing ERK and inducing PPAR gamma DNA binding. Biochem. Pharmacol. 84: 16811690. http://dx.doi.org/10.1016/j.bcp.2012.09.033

Mahali SK, Verma N and Manna SK (2014). Advanced glycation end products induce lipogenesis: regulation by natural xanthone through inhibition of ERK and NF-кB. J. Cell. Physiol. 229: 1972-1980. http://dx.doi.org/10.1002/ jсp. 24647

Mahmoud AA and Elshazly SM (2014). Ursodeoxycholic acid ameliorates fructose-induced metabolic syndrome in rats. PLoS One 9: e106993. http://dx.doi.org/10.1371/journal.pone.0106993

Matsui T, Yamagishi S, Takeuchi M, Ueda S, et al. (2010). Nifedipine inhibits advanced glycation end products (AGEs) and their receptor (RAGE) interaction-mediated proximal tubular cell injury via peroxisome proliferator- 
activated receptor-gamma activation. Biochem. Biophys. Res. Commun. 398: 326-330. http://dx.doi.org/10.1016/j. bbrc.2010.06.093

Rahigude AB, Kaulaskar SV and Bhutada PS (2012). Possible therapeutic potential of berberine in diabetic osteopathy. Med. Hypotheses 79: 440-444. http://dx.doi.org/10.1016/j.mehy.2012.06.016

Wang SH, Guo YJ, Yuan Y, Li L, et al. (2011). PPAR $\gamma$-mediated advanced glycation end products regulate neural stem cell proliferation but not neural differentiation through the BDNF-CREB pathway. Toxicol. Lett. 206: 339-346. http:// dx.doi.org/10.1016/j.toxlet.2011.07.026

Xu SH, Wang KF, Xu CS and Xie LD (2011). Effect of atorvastatin on advanced glycation end products induced monocyte chemoattractant protein-1 expression in cultured human endothelial cells. Zhonghua. Xin Xue Guan Bing ZaZhi 39: 512-517.

Zhang Y, Luo Z, Ma L, Xu Q, et al. (2010). Resveratrol prevents the impairment of advanced glycosylation end products (AGE) on macrophage lipid homeostasis by suppressing the receptor for AGE via peroxisome proliferator-activated receptor gamma activation. Int. J. Mol. Med. 25: 729-734. 